\title{
A Numerical Taxonomic Survey of Listeria and Related Bacteria
}

\author{
By BRENDA J. WILKINSON AND DOROTHY JONES \\ Department of Microbiology, School of Biological Sciences, \\ The University, Leicester $L E_{\mathrm{I}}{ }_{7} R H$
}

(Received 12 August 1976)

\begin{abstract}
SUMMARY
A numerical taxonomic study was performed on named strains of Listeria, Erysipelothrix, Microbacterium thermosphactum, Lactobacillus, Streptococcus, Propionibacterium, Kurthia and some possibly related bacteria using I43 unit characters covering a wide range of properties. The strains fell into six main clusters: (A) Listeria; (B) Microbacterium thermosphactum, Lactobacillus, Streptococcus; (C) Gemella, Erysipelothrix; (D) Kurthia and mainly aerobic corynebacteria; (E) Propionibacterium, Staphylococcus; (F) mainly Cellulomonas.

The genus Listeria contained three subgroups corresponding to (I) Listeria monocytogenes, (2) Listeria grayi and (3) non-haemolytic listeria strains. Listeria murrayi did not appear to be sufficiently distinct from Listeria grayi to warrant separate species status. The genus Erysipelothrix was quite separate from the genus Listeria. Microbacterium thermosphactum was related to both the genera Listeria and Lactobacillus but formed a separate phenon that could appropriately be given generic rank. There were four distinct subgroups amongst the streptococci examined. Gemella strains appeared as a distinct phenon related to Erysipelothrix and the streptococci. The lactobacilli grouped into four phena largely corresponding to the subgenera Betabacterium, Streptobacterium and Thermobacterium and to the species Lactobacillus mali.

Clusters $\mathrm{A}, \mathrm{B}$, and $\mathrm{C}$ displayed a relatively close association to each other and it is recommended that all be included in the family Lactobacillaceae.
\end{abstract}

\section{INTRODUCTION}

The genus Listeria was created to accommodate Listeria monocytogenes, first described by Murray, Webb \& Swann (1926) as the causative organism of a septicaemic disease of rabbits. For many years a monospecific genus, Listeria now contains the additional species List. denitrificans, List. grayi and List. murrayi (Buchanan \& Gibbons, 1974). However, the taxonomic relationships within the genus and between it and allied Gram-positive taxa are not clear. The genus Listeria was classified in the family Corynebacteriaceae (Breed, Murray \& Smith, 1957), but in the 8th edition of Bergey's Manual of Determinative Bacteriology (Buchanan \& Gibbons, 1974) it is treated with Erysipelothrix and Caryophanon as 'genera of uncertain affiliation' in a section which also contains lactobacilli.

The early literature on List. monocytogenes is well documented by Seeliger (I96I) and more recent work (Errebo Larsen \& Seeliger, I966; Welshimer \& Meredith, 1971 ; Stuart \& Welshimer, 1973, 1974; Jones, 1975a; Wilkinson \& Jones, 1975) indicates a close relationship between List. monocytogenes, List. grayi and List. murrayi, but there is disagreement on whether the relationship between the three taxa is consistent with three species in one genus (see Jones, I975b). Recent studies indicate that List. denitrificans should be removed from 
the genus Listeria (Stuart \& Pease, I972; Stuart \& Welshimer, 1973, 1974; Jones, 1975a; Wilkinson \& Jones, 1975).

Most numerical taxonomic studies suggest that List. monocytogenes is more closely related to the lactic acid bacteria than to the coryneform bacteria (Sneath \& Cowan, I958; Davis et al., 1969; Stuart \& Pease, I972; Wilkinson, 1973; Jones, 1975a), though some also indicate a relationship between List. monocytogenes and the genus Kurthia and some animal corynebacteria (Da Silva \& Holt, I965; Davis \& Newton, I969).

In the present study, representatives of all the species of the genus Listeria and of the genera Corynebacterium, Kurthia, Erysipelothrix, Lactobacillus, Streptococcus, Gemella, Staphylococcus, Micrococcus and other Gram-positive bacteria received as 'Brevibacterium', 'Arthrobacter' and 'Bacterium eurydice' were examined by numerical taxonomic methods. The 'Arthrobacter' strains were isolated from clinical material and were included because a previous study (Jones, 1975a) suggested a possible relationship between these strains and List. denitrificans.

\section{METHODS}

Strains. These are listed in Table I. A few were fresh isolates, but the majority were received from other workers or from culture collections. Type strains were included if possible. To encourage objectivity during scoring of the results, each strain was handled unnamed under a study number $(G)$. Non-haemolytic variants of two List. monocytogenes strains (GI5 and Gi6) which appeared during preliminary culture were retained in the study as Gi5A and Gi6A. All bacterial strains were lyophilized and working cultures were maintained on BM medium (see below).

Basal medium. In numerical taxonomic work it is important to select one medium which allows good growth of all the bacteria and can be used alone or with slight modifications as the basal medium for most of the tests. Of a number of basal media investigated, the most suitable was the MRS medium of De Man, Rogosa \& Sharpe (1960) with acetate and citrate omitted. This modified MRS medium was used as a solid and liquid medium and is subsequently referred to as BM agar and BM broth. The bacteria used for the inoculation of all tests were $24 \mathrm{~h}$ cultures grown on BM agar or broth.

Choice of incubation temperature. Microbacterium thermosphactum will not grow at $35^{\circ} \mathrm{C}$ whereas certain lactobacilli and streptococci grow weakly or not at all at $30^{\circ} \mathrm{C}$. Since the majority of the strains grew well at $35^{\circ} \mathrm{C}$, this was chosen as the main incubation temperature. Microbacterium thermosphactum and a representative selection of 46 strains from other genera were incubated at $30^{\circ} \mathrm{C}$. The representative strains were also grown at $35^{\circ} \mathrm{C}$ so that any variation produced by incubating at different temperatures and the effect this might have on the subsequent clustering of the bacteria could be determined.

Colonial and cell morphology. Bacteria were grown on blood agar base (Oxoid) plus $7 \%$ ( $\mathrm{v} / \mathrm{v}$ ) sterile horse blood. Haemolysis ( $\alpha$ or $\beta$ ) was recorded at I and 2 days. Colonial morphology was examined under a low power microscope at $\mathrm{I}$ and 4 days at $\times 100$ and $\times 400$ magnification. Gram stains were performed (see Collins \& Lyne, 1970) at the same time and examined at $\times 1000$ magnification.

Growth characteristics in liquid medium were examined in BM broth at I and 4 days. Motility was examined by the hanging drop technique at $\times 400$ magnification using $\mathrm{BM}$ broth cultures incubated for I day.

Growth at different temperatures. Bacteria were incubated in tubes of BM broth in water baths maintained at $5,10,20,30,35,45$ and $50^{\circ} \mathrm{C} \pm \mathrm{I}{ }^{\circ} \mathrm{C}$. Growth was recorded daily for up to $2 \mathrm{I}$ days at $5{ }^{\circ} \mathrm{C}$, I4 days at 10 and $20^{\circ} \mathrm{C}$, and up to 7 days at all other temperatures. 
Table I. Strains studied

Study no. Name as received

Source and collection no.*

Hill A I 37/68

Brzin

Bailey

Bailey

Bailey

ATCC 953

NCIB8 I43

NCIB 9397

ATCC8365

ATCC 9174

ATCCr 3809

ATCCI 4403

NCIB8077

NCIB8I42

NCIB8980

$\mathrm{NCIB8073}$

NCIB8074

ATCC 49 I

$\mathrm{NCPPB}_{3} 63$

$\mathrm{NCTC} 3984$

NCPPB 1488

NCPPB83

NCIB9097

NCIB 7206

NCPPB 1468

NCPPB844

NCPPB 797

Wellcome CN57 I, Woodbine

Wellcome CN354, Woodbine

Wellcome CN446, Woodbine

Wellcome CN906, Woodbine

Wellcome CN2432, Woodbine

Wellcome CN6260, Woodbine

S52, Woodbine

NCTC8 163

Sneath 13

Sneath 49

Sneath 19

Sneath 45

NCTCIO459

NCTC10243

NCTCIO244

$\mathrm{NCTC}_{4} \mathrm{O} 4$

Gardner 26

Gardner 33

Gardner 38

Gardner 3I

Gardner 34

Gardner 76

Keddie K2

Keddie S8

Keddie $\mathbf{S} 9$

ATCC 4356

ATCCI9992

ATCC 14869

ATCC 4005

ATCCII 842

${ }_{\text {ATCC } 393}$

ATCC 7469

ATCCI 1739
Origin or comments

Throat

Throat

Honey bee

Honey bee

Honey bee

Co-type

Co-type $†$

Holotype

Co-type

Holotype $\uparrow$

Co-type

Same as NCIB8978

-

Co-type ${ }^{\prime}$

Co-type $†$

Suggested working type $\dagger$

-

$\exists$

Pheasant, London Zoo

Suggested working type $\dagger$

Human

Human

Human

Human

Suggested working type

Hamburger

Frozen minced pork

Pork sausage

Fat trimmings

Rendered lard

Pork sausage

Milk

Meat

Meat

Suggested working type $\dagger$

Co-type $\dagger$

Suggested working type $\dagger$ Suggested working type $†$ Co-type $\uparrow$

Co-typet

* Abbreviations: ATCC, American Type Culture Collection; NCDO, National Collection of Dairy Organisms; NCIB, National Collection of Industrial Bacteria; NCPPB, National Collection of Plant Pathogenic Bacteria; NCTC, National Collection of Type Cultures; P.I.C., Pasteur Institute Collection; Bailey, L., Rothamstead Experimental Station, Harpenden, Hertfordshire; Board, R. G., Dept of Microbiology, University of Bath; Brzin, B., St Vincent's Hospital, Adelaide, Australia; Carr, J. G., Long Ashton Research Station, Bristol; Elliott, S. D., Dept of Pathology, University of Cambridge; Gardner, G. A., Ulster Curers' Association, Belfast; Hill, L. R. Central Public Health Laboratory, Colindale, London NW9; Jones, D., Dept of Microbiology, University of Leicester; Keddie, R. M., Dept of Microbiology, University of Reading; Kellogg, D. S., Communicable Disease Center, Atlanta, Georgia, U.S.A.; Khan, M. A., Dept of Microbiology, University of Nottingham, Sutton Bonnington; Kitchell, A. G., Meat Research Institute, Langford, Bristol; Lord, A., Dept of Microbiology, University of Leicester; Mair, N. S., Public Health Laboratory, Leicester; Murray, R. G. E., Dept of Bacteriology, University of Western Ontario, Canada; Seeliger, H. P. R., Insitutute for Hygiene \& Microbiology, University of Würzburg, Germany; Sneath, P. H. A., Dept of Microbiology, University of Leicester; Wellcome, The Wellcome Foundation, Beckenham, Kent; Wood, D., Dept of Microbiology, University of Leicester; Woodbine, M., Dept of Microbiology, University of Nottingham, Sutton Bonnington.

+ From Sneath \& Skerman (1966). 
Study no. Name as received

$\begin{array}{ll}\text { G81 } & \text { Lact. delbrueckii } \\ \text { G68 } & \text { Lact. delbrueckii } \\ \text { G69 } & \text { Lact. fermentum } \\ \text { G70 } & \text { Lact. fermentum } \\ \text { G71 } & \text { Lact. fermentum } \text { II } \\ \text { G72 } & \text { Lact. helveticus } \\ \text { G73 } & \text { Lact. jugurt } \\ \text { G74 } & \text { Lact. jugurt } \\ \text { G75 } & \text { Lact. lactis } \\ \text { G76 } & \text { Lact. leichmannii } \\ \text { G142 } & \text { Lact. mali } \\ \text { G143 } & \text { Lact. mali }\end{array}$

Gi43 Lact. mali

Gr44 Lact. mali

$\mathrm{G}_{77} \quad$ Lact. plantarum

G78 Lact. salivarius subsp. salivarius

G79 Lact. salivarius subsp. salicinius

G80 Lactobacillus sp.

GI Listeria denitrificans

$\mathrm{G}_{43} \quad$ List. denitrificans

G2 List. grayi

G3 List. grayi

G42 List. grayi

G47 List. grayi

G5 List. monocytogenes

G6 List. monocytogenes

G7 List. monocytogenes

G Io List. monocytogenes

GI I List. monocytogenes

Gi2 List. monocytogenes

Gi3 List. monocytogenes

Gi4 List. monocytogenes

Gi5 List monocytogenes

Gi5A List. monocytogenes

Gi6 List. monocytogenes

Gi6A List, monocytogenes

G17 List. monocytogenes

Gi 8 List. monocytogenes

Gi9 List. monocytogenes

G20 List. monocytogenes

G2I List. monocytogenes

G22 List. monocytogenes

G23 List. monocytogenes

G24 List. monocytogenes

List. monocytogenes

List. monocytogenes

List. monocytogenes

List. monocytogenes

List, monocytogenes

List. monocytogenes

List. monocytogenes

List. monocytogenes

List. monocytogenes

List. monocytogenes

List. monocytogenes

List. monocytogenes

List. monocytogenes

List. monocytogenes

List. monocytogenes

List. monocytogenes

List. murrayi

List. murrayi

List. murrayi

Listeria sp.

Listeria sp.

Listeria sp.

Listeria sp.

Microbacterium thermosphactum

Micro. thermosphactum

Micro. thermosphactum

Micro. thermosphactum

Micro. thermosphactum

Micro. thermosphactum

Micro. thermosphactum

II ficro, thermosphactum
Table I (cont.)

Source and collection no.*

Origin or comments

NCDOr744

ATCC 49

ATCCr4932

ATCC23272

ATCCi5009

ATCC52I

ATCC7993

ATCCI2315

ATCC 4797

Carr 12

Carr 123

Carr 26

ATCCr4917

ATCCI I74I

ATCCI1742

$\mathrm{NCDO} 204$

Seeliger L84/68

P.I.C.55134, L26

Seeliger L56/66

Seeliger W-L96/65

Seeliger L332/64

ATCC25400

Murray 148

Murray 149

Murray 44

Murray 104

Murray 127

Murray I28

Murray I33

Murray 134

Murray I 39

Murray 139

Murray I40

Murray I40

Murray I4I

Mair

Mair 2825I

Mair 17

Mair 2643 I

NCTC 5348

NCTC10357

NCTC5IO5

NCTC4885

Seeliger L88/7

Mair or 7

NCTC4885

NCTC5105

NCTC52 I4

NCTC 5348

NCTC7973

$\mathrm{NCTC}_{4883}$

Wood

Brzin

Mair

Jones

Khan 560

Khan 6II

Khan 611

ATCC2540I

ATCC25402

ATCC25403

Mair 24733

Murray 50

Murray 5 I

Sneath 155

Kitchell IA (BaAI)

Kitchell I 24 (BaA6)

Kitchell I3 (BaV3)

Kitchell I $3 \mathrm{~A}\left(\mathrm{BaV}_{3}\right)$

Kitchell I3B ( $\left.\mathrm{BaV}_{3}\right)$

Kitchell 144 (BfA9)

Kitchell I 56 (BfV9)

Kitchell IOI (LfA3)
Suggested working type $\nmid$

$\underline{-}$

-

Co-type

Suggested working type $\dagger$

Cider

Cider

Cider

Suggested working typet

Holotype $\uparrow$

Co-type ${ }^{\dagger}$

Type strain

Chinchilla

Wolf-coyote hybrid

Wolf-coyote hybrid

Ferret

Arctic fox

Wild snowshoe hare

Moose brain

Tick

Spring water

Trout

Trout

Trout

Trout

Mud

Human

Human

Human

Human

Holotype

Rough strain from Pote

$-$

-

Holotype

Calf

Human

Human

Calf brain

Non-haemolytic

Human

Cow brain

Human tonsil

Human

Beef

Beef

Beef

Beef

Beef

Beef

Beef

Lamb

For footnotes see p. 401 . 
Table I (cont.)

Study no. Name as received

Micro. thermosphactum

Micro. thermosphactum

Micro. thermosphactum

Micro. thermosphactum

Micro. thermosphactum

Micro. thermosphactum

Micro. thermosphactum

Micro. thermosphactum

Micro. thermosphactum

Micro. thermosphactum

Micro. thermosphactum

Micro. thermosphactum

Micro. thermosphactum

Micro. thermosphactum

Micro. thermosphactum

Micro. thermosphactum

Micro. thermosphactum

Micrococcus agilis

Micrococcus denitrificans

Micrococcus hyicus

Micrococcus luteus

Neisseria haemolysans

Propionibacterium freudenreichii

Prop. pentosaceum

Prop. peterssonii

Prop. shermanii

Staphylococcus aureus

Staph. aureus

Staph. epidermidis

Staph. saprophyticus

Streptococcus agalactiae

Strep. bovis

Strep. durans

Strep. equi

Strep. equinus

Strep. faecalis

Strep. faecium

Strep. faecalis var. liquefaciens

Strep. faecalis var. zymogenes

Strep. pyogenes

Strep. suis

Strep. suis

Strep. suis

Strep. suis

Strep. suis

Strep, suis

Strep, uberis

Streptococcus sp.

Streptococcus sp.

Streptococcus sp.

Streptococcus sp.

Streptococcus sp.

GI330

Streptococcus sp.

Streptococcus sp.

Streptococcus sp.

Streptococcus sp.

Streptococcus sp.

Streptococcus sp.

Streptococcus sp.
Source and collection no.*

Kitchell 46 (LfVI)

Kitchell I 28 (LfV6)

Kitchell WR7

Kitchell CR I 2a

Kitchell 30

Kitchell zoa

NCIB 100 I8

Lord I

Lord 2

Lord 3

Lord I I

Lord 33

Gardner 44

Gardner 52

Gardner 54

Gardner 58

NCTC2676

NCIB8944

NCTCro350

NCTC8512

Kellogg

NCIB5959

NCIB8070

NCIB5962

NCIB8099

NCTC8532

NCTC657I

NCTC729

NCTC7292

NCTC8 I8I

NCTC8I77

NCTC8307

NCTC9682

ATCC98 12

NCTC775

NCTC7171

NCTC8I75

NCTC8I 76

NCTC8198

Elliott PM

Elliott PM35

Elliott PM$_{37}$

Elliott 596/70

Elliott $627 / 70$

Elliott $34 / 70$

$\mathrm{NCTC}_{3} 858$

NCTC5385

NCTC 5389

NCTC 8547

$\mathrm{NCTC}_{7} 868$

NCTC 5338

NCTC5338

NCTCI0238

NCTC7760

NCTC668 I

NCTC8029

NCTC9938

Board
Origin or comments

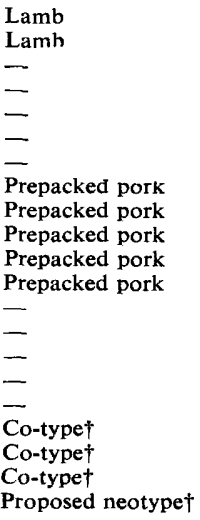

-

Suggested working type $\dagger$ Suggested working type $\dagger$ Suggested working type $\uparrow$

Proposed neotype $\dagger$

'Oxford strain'

ב

Neotype $†$

Co-typet

$-$

Suggested working type $\dagger$ Suggested working type $\dagger$

Suggested working type $\uparrow$

Pig

Pig

Pig

$-$

Co-type $\dagger$

Serological gp E

Serological gp F

Serological gp G

Serological gp H

Serological gp K, opaque

variant

Serological gp K, transparent

variant

Serological gp L

Serological gp M

Serological gp $\mathbf{N}$

Serological gp O

Serological gp Q

Sausage

For footnotes see p. 401 .

Survival at $60{ }^{\circ} \mathrm{C}$ for $15 \mathrm{~min}$. Bacteria grown in BM broth for $18 \mathrm{~h}$ were placed in a water bath maintained at $60 \pm \mathrm{I}{ }^{\circ} \mathrm{C}$ for $\mathrm{I} 5 \mathrm{~min}$, then immediately cooled and two drops from each tube were plated on BM agar. The plates were observed for growth at I and 2 days.

Anaerobic growth. Duplicate tubes of BM broth were inoculated: one was incubated in an anaerobic jar under hydrogen, the other in air. Growth was recorded after 5 days.

Catalase and oxidase. Bacterial growth on $\mathrm{BM}$ agar was used for these tests. $\mathrm{H}_{2} \mathrm{O}_{2}$ 
(20 vol.) was used to test for catalase; oxidase was tested for by the method of Klinge (1960). A positive result was scored if a purple colour developed within $30 \mathrm{~s}$.

Production of acid from carbohydrates. A modification of BM medium was used containing $\left(\mathrm{g} \mathrm{l}^{-1}\right)$ : peptone (Oxoid), I5; yeast extract (Oxoid), I; Tween 80 (Koch-Light), I; $\mathrm{K}_{2} \mathrm{HPO}_{4}, 2 ; \mathrm{MgSO}_{4} \cdot 7 \mathrm{H}_{2} \mathrm{O}, 0.2 ; \mathrm{MnSO}_{4} \cdot 4 \mathrm{H}_{2} \mathrm{O}, 0.05 ;$ agar (Oxoid no. I), I0; $\mathrm{pH} 7 \cdot 0$. For liquid medium, the agar was omitted. These media are subsequently referred to as SBM agar and SBM broth. Filter-sterilized aqueous solutions of the appropriate carbohydrates were added to the sterilized SBM medium to give a final concentration of $\mathrm{I} \%(\mathrm{w} / \mathrm{v})$. The indicator was $2 \%$ aqueous bromocresol purple $\left(1 \cdot 5 \mathrm{ml} \mathrm{l}^{-1}\right)$. The medium was dispensed into divided dishes, inoculated as described by Stevens (1969) and examined for acid production at I, 2, 3 and 4 days.

Oxidativelfermentative utilization of glucose. The method of Hugh \& Leifson (1953) was used except that the basal medium was SBM broth plus $\mathrm{I} \%$ aqueous bromocresol purple $\left(3 \mathrm{ml} \mathrm{l}^{-1}\right)$ and $0.4 \%(\mathrm{w} / \mathrm{v})$ agar (Oxoid no. I). Tubes were examined at frequent intervals for up to 14 days.

Gas production from glucose. Tubes of SBM broth plus I \% (w/v) filter-sterilized glucose and containing inverted Durham tubes were inoculated, incubated and inspected for the accumulation of gas in the Durham tube at I, 2, 5 and 7 days.

Gluconate oxidation. Tubes of SBM broth plus I \% (w/v) gluconate were inoculated and incubated for 8 days. A Clinitest tablet (Ames Co., Slough) was then added to I $\mathrm{ml}$ of the growth medium. An orange colour indicated the presence of a reducing sugar (i.e. glucose), a blue one its absence.

Production of slime from sucrose. A filter-sterilized solution of sucrose was added to sterile SBM agar to give a final concentration of $\mathrm{I} \%(\mathrm{w} / \mathrm{v})$. The medium was dispensed in divided dishes and inoculated as described by Stevens (1969). Growth was inspected for slime formation at $\mathrm{I}$ and 2 days.

Methyl red and Voges Proskauer (VP) tests. BM broth [with glucose reduced to $0.5 \%(\mathrm{w} / \mathrm{v})$ and $\mathrm{K}_{2} \mathrm{HPO}_{4}$ increased to $0.5 \%(\mathrm{w} / \mathrm{v})$ ] was dispensed in $12.5 \mathrm{ml}$ amounts in $25 \mathrm{ml}$ screwcapped bottles. After incubation, portions of the growth medium were tested as described by Cowan \& Steel (I965), Barritt's method being used for the VP reaction.

Litmus milk. The medium and method of Wheater (1955) were used. Cultures were examined at I, 2, 5 and 9 days for reduction before clotting, acid production, alkali production, clotting and digestion.

Carbon sources. Growth in SBM broth and in SBM broth containing the substrate under test were compared at 5 days by absorbance readings in a Bausch \& Lomb spectrophotometer at $540 \mathrm{~nm}$. Positive results were scored only when growth in the medium containing substrate was at least twice that in the basal broth.

Ammonia from peptone. SBM medium containing bromocresol purple $(0.003 \%, \mathrm{w} / \mathrm{v})$ was dispensed in divided dishes and inoculated as described by Stevens (1969). Plates were examined for the appearance of a deep purple colour at 1, 2, 5 and 7 days.

Sensitivity to antibiotics. Petri dishes containing BM medium were lawned with $0.1 \mathrm{ml}$ of $48 \mathrm{~h}$ broth cultures by means of a sterile glass spreader. Antibiotics in the form of 'Sentest' discs (Evans Medical, Liverpool) were then placed on to the growth (4 per plate). The concentrations of antibiotics are listed by Johnson \& Sneath (I973). Zones of total and partial inhibition and, in the case of sulphonamide, stimulation of growth were recorded after $24 \mathrm{~h}$ and $48 \mathrm{~h}$.

Cellulose hydrolysis. Cellulolytic activity was investigated by inoculating strains into tubes of BM broth (minus glucose) containing strips of Whatman no. I filter paper, half the 
length of which was above the level of the liquid. The tubes were examined at frequent intervals for up to ro weeks. A positive result was recorded if the filter paper disintegrated completely at the liquid/air interface.

Casein hydrolysis. An equal volume of $\mathrm{I} \%(\mathrm{w} / \mathrm{v})$ skim milk (Marvel; Cadbury, Bournville, Birmingham) in distilled water, sterilized by autoclaving at $120^{\circ} \mathrm{C}$ for $15 \mathrm{~min}$, was added to sterile BM agar $(2 \times$ normal agar concentration $)$ and dispensed in Petri dishes. Cultures were streaked to give one line of growth and examined for areas of clearing for up to 15 days.

Lecithinase. Sterile lecithin (Oxoid, SR47), to give a final concentration of I \% (v/v), was added to cool, sterile BM agar (with glucose reduced to $0 . \mathrm{I} \%$ ) and dispensed in Petri dishes. Cultures were streaked to give one line of growth, incubated and inspected for zones of clearing and/or precipitation after I, 2 and 8 days.

Deoxyribonuclease and ribonuclease. Bacteria were grown on BM agar plus $0.08 \%(\mathrm{w} / \mathrm{v})$ $\mathrm{CaCl}_{2}$ and $0.2 \%(\mathrm{w} / \mathrm{v})$ deoxyribonucleic acid or $0.2 \%(\mathrm{w} / \mathrm{v})$ ribonucleic acid, dispensed in Petri dishes. Cultures were streaked in one line of growth. After 6 days incubation they were examined for zones of clearing. In the case of doubtful positive results, the plates were flooded with $\mathrm{I} \mathrm{M}-\mathrm{HCl}$ and then inspected for zones of clearing.

Urease and hydrogen sulphide production. The medium consisted of $40 \mathrm{ml} 50 \%(\mathrm{w} / \mathrm{v})$ aqueous urea solution (sterilized by filtration) added to I 1 of sterile molten BM agar (glucose reduced to $0.5 \%(\mathrm{w} / \mathrm{v})$, but with $5 \mathrm{ml} 2 \%(\mathrm{w} / \mathrm{v})$ phenol red added as indicator). The medium was dispensed in $5 \mathrm{ml}$ quantities in test-tubes, allowed to set as slopes and inoculated. Strips of lead acetate paper were then inserted between the cap and the tube. After incubation, the tubes were inspected for blackening of the lead acetate paper and for development of a red colour in the medium at I, 4, 7, I I, I4 and 2 I days.

Tween hydrolysis. Tween 20, 40, 60 and 80 (Koch-Light), at final concentrations of I \% (v/v), were added to BM agar minus Tween 80 and with glucose at I \% (w/v). After sterilization at $120^{\circ} \mathrm{C}$ for $15 \mathrm{~min}$, the medium was dispensed in Petri dishes and inoculated as described for casein hydrolysis. Zones of precipitation and of clearing were recorded at frequent intervals up to $2 \mathrm{I}$ days.

Tyrosine and xanthine hydrolysis. BM agar (minus glucose) containing $0.5 \%(\mathrm{w} / \mathrm{v})$ L-tyrosine or $0.5 \%(\mathrm{w} / \mathrm{v})$ xanthine was autoclaved at $120^{\circ} \mathrm{C}$ for $\mathrm{I} 5 \mathrm{~min}$ and dispensed into Petri dishes, care being taken to ensure even distribution of the substrate. Plates were inoculated as described for casein hydrolysis and inspected for zones of clearing at frequent intervals up to $2 \mathrm{I}$ days.

Phosphatase and sulphatase. A I \% (w/v) aqueous solution of phenolphthalein diphosphate (Na salt: $\mathrm{BDH}$ ) or phenolphthalein disulphate (K salt: Koch-Light), sterilized by filtration, was added to sterile molten BM agar to give a final concentration of $0.00 \mathrm{I} \%(\mathrm{w} / \mathrm{v})$. The medium was dispensed in Petri dishes and inoculated to give well-separated colonies. After 6 days, $\mathrm{I} \mathrm{ml} \mathrm{concentrated} \mathrm{ammonia} \mathrm{solution} \mathrm{was} \mathrm{placed} \mathrm{in} \mathrm{the} \mathrm{lid} \mathrm{of} \mathrm{each} \mathrm{inverted} \mathrm{dish} \mathrm{and}$ allowed to stand for $10 \mathrm{~min}$. A positive reaction was indicated by the appearance of a pink colour around the colonies due to the free phenolphthalein reacting with the ammonia vapour.

Aesculin hydrolysis. The method of Sneath (1960) was used, but the medium was SBM broth supplemented with $\left(\mathrm{g} \mathrm{l}^{-1}\right)$ : sodium citrate, I; aesculin, I; ferric citrate scales, 0.05 . The ferric citrate scales were dissolved by boiling in a small volume of water and added to the medium which was dispensed in 3 to $4 \mathrm{ml}$ quantities in $6 \mathrm{ml}$ bottles and sterilized at $120^{\circ} \mathrm{C}$ for $15 \mathrm{~min}$. After inoculation and incubation, blackening and loss of purple fluorescence were recorded at $I$ and 5 days.

Arginine deamination. The method of Thornley (1960) was used except that SBM broth 
was used as the basal medium. Tests were performed with and without the liquid paraffin layer and tubes were inspected for the appearance of pink colour after 2 and 5 days.

Hippurate hydrolysis. SBM broth containing $1 \%(\mathrm{w} / \mathrm{v})$ sodium hippurate and $0.1 \%$ $(\mathrm{w} / \mathrm{v})$ glucose, and sterilized by autoclaving at $120^{\circ} \mathrm{C}$ for $15 \mathrm{~min}$, was dispensed in $10 \mathrm{ml}$ quantities in $25 \mathrm{ml}$ bottles, inoculated and incubated for 7 days. Each culture was then centrifuged and two I $\mathrm{ml}$ samples were removed; to one was added I $\mathrm{ml} \mathrm{I} 2 \%(\mathrm{w} / \mathrm{v})$ $\mathrm{FeCl}_{3} \cdot 6 \mathrm{H}_{2} \mathrm{O}$, and to the other I ml $50 \%(\mathrm{v} / \mathrm{v}) \mathrm{H}_{2} \mathrm{SO}_{4}$ (Davis, I955). Both test methods were used because weak positive reactions are frequently only detected by the $\mathrm{H}_{2} \mathrm{SO}_{4}$ method.

Starch hydrolysis. A $10 \%(\mathrm{w} / \mathrm{v})$ aqueous starch solution was dissolved by heating and added to BM agar (minus glucose) to give a final concentration of $0.2 \%(\mathrm{w} / \mathrm{v})$. After sterilization at $120^{\circ} \mathrm{C}$ for $15 \mathrm{~min}$, the medium was dispensed into Petri dishes and inoculated as for casein hydrolysis. After 15 days incubation the dishes were flooded with iodine solution and examined for clearing under and around the growth.

Indole production from tryptone. The medium [containing $\left(\mathrm{g}^{-1}\right)$ : tryptone (Oxoid), 20; $\mathrm{K}_{2} \mathrm{HPO}_{4}, 2$; glucose, $2 ; \mathrm{MgSO}_{4} .7 \mathrm{H}_{2} \mathrm{O}, 0.2 ; \mathrm{MnSO}_{4} .4 \mathrm{H}_{2} \mathrm{O}, 0.05 ; \mathrm{pH} 7 \cdot 2$ ] was dispensed into test-tubes in $7 \mathrm{ml}$ quantities. After inoculation, the broths were incubated for 16 days and tested by method 2 of Cowan \& Steel (1965).

Nitrate reduction. Bacteria were inoculated into $\mathrm{BM}$ broth plus $0 . \mathrm{I} \% \mathrm{KNO}_{3}$ dispensed in Io $\mathrm{ml}$ quantities in tubes containing an inverted Durham tube. The tubes were examined at 2 and 8 days for the presence of gas. At the same time, samples were removed and tested for the presence of nitrite as described by Wilson \& Miles (1964). Negative tests were checked at 8 days by adding zinc dust to reduce residual nitrate to nitrite.

Sensitivity to nitrite. Bacteria were inoculated into BM broth plus $0.01 \% \mathrm{KNO}_{2}$ dispensed in $5 \mathrm{ml}$ quantities in test tubes; BM broth alone was also inoculated as a control. Growth was compared visually in the two media at 2 and 8 days.

Sodium chloride. Bacteria were inoculated into tubes containing $5 \mathrm{ml} \mathrm{BM}$ broth plus 6.5 or $10 \%(\mathrm{w} / \mathrm{v}) \mathrm{NaCl}$ and into tubes of $\mathrm{BM}$ broth alone. After incubation, the tubes were examined for growth at $\mathrm{I}, 2$ and 7 days.

Inhibition by potassium thiocyanate and thallous acetate. BM agar containing potassium thiocyanate $(2.5,3.75$ or $4.5 \%, \mathrm{w} / \mathrm{v})$ or thallous acetate $(0.0 \mathrm{I}, 0.02$ or $0.03 \%, \mathrm{w} / \mathrm{v})$ was dispensed in divided dishes and inoculated as described by Stevens (I969). Growth was compared with that on BM agar alone at I and 2 days.

Potassium tellurite. A $10 \%(\mathrm{w} / \mathrm{v})$ aqueous solution of potassium tellurite, sterilized by autoclaving at $120^{\circ} \mathrm{C}$ for $15 \mathrm{~min}$, was added to sterilized BM agar to give final concentrations of $0.01,0.025$ and $0.05 \%(\mathrm{w} / \mathrm{v})$. The medium was dispensed and inoculated as described for potassium thiocyanate. Growth and degree of blackening were compared with that on BM agar alone at $\mathrm{I}$ and 2 days.

Tetrazolium. A filter-sterilized aqueous solution of 2,3,5-triphenyltetrazolium chloride (I0 \%, w/v) was added to sterile SBM agar to give final concentrations of 0.01 and $0 . \mathrm{I} \%$ $(\mathrm{w} / \mathrm{v})$. The medium was dispensed and inoculated as described for potassium thiocyanate. Growth and reduction of tetrazolium were compared with that on SBM agar alone at I and 2 days.

Coding of characters. Those characters which existed in one or two mutually exclusive states were scored I (plus) and o (minus). Multistate characters, e.g. degree of acid production, were scored o (minus), I (weak positive) and 2 (strong positive).

Computation. The simple matching coefficient $\left(S_{\mathrm{SM}}\right)$ (Sokal \& Michener, I958) was used and clustering was achieved by both single linkage (Sneath, I957) and unweighted pair- 
group average linkage (Sokal \& Michener, I958). The IGROUPS (integer groups) program printed character-value statistics on specified groups of bacteria. This program, devised by M. J. Sackin of this Department, aided the selection of tests important in the characterization of taxonomic groups. A further program PRINTRES, written by B. J. Wilkinson and M. J. Sackin, printed out the raw data. All calculations were carried out on the ICL 4I30 computer at Leicester University.

The maximum number of strains which could be computed at one time was 180 , therefore thirteen of the 193 strains included in the study were omitted in the first computation (computation A). As mentioned above, 46 strains were tested for all characters at both 30 and $35{ }^{\circ} \mathrm{C}$. These duplicate sets of results, together with a single set of results for a further 88 strains (including the strains omitted in the first computation), were computed separately (computation B). A further computation was carried out on those strains (area I of computation A) which showed the closest relationship to Listeria and the K. zopfii strains.

\section{RESULTS}

\section{Computation A}

All strains except Micro. thermosphactum (G86 to G97 inclusive) and Micrococcus agilis (GI8r) were included in the first computation. The Micro. thermosphactum strains included were incubated at $30{ }^{\circ} \mathrm{C}$, the remainder of the strains at $35^{\circ} \mathrm{C}$.

At the $67 \%$ similarity level $(\% \mathrm{~S})$, all I 80 strains fell into two main areas (I and II). At just below $75 \% \mathrm{~S}$, these areas contained six distinct clusters (A, B, C, D, E, F) with varying degrees of homogeneity. The quantitative taxonomic relationships within and between the clusters are illustrated in Fig. I.

Cluster A: Listeria. Above $80 \% \mathrm{~S}$ this cluster contained three subgroups and one single strain. Subgroup AI with an internal similarity of $87 \%$, contained all strains received as List. monocytogenes, two received as Listeria sp., and one received as List. denitrificans (GI) which biochemically and serologically was typical of List. monocytogenes. Subgroup A2, with an internal similarity of $90 \%$, contained all strains received as List. grayi and List. murrayi and joined the type strain of List. denitrificans $\left(\mathrm{G}_{43}\right)$ at approximately $85 \% \mathrm{~S}$. Subgroup A3 contained three non-haemolytic listeria strains.

Cluster B: Lactobacillus (in part), Micro. thermosphactum, Propionibacterium, Streptococcus (in part). This cluster comprised six subgroups. Subgroup BI, with an internal similarity of $80 \%$, contained strains of Lact. casei, Lact. plantarum and Lact. salivarius plus strains received as E. rhusiopathiae $\left(\mathrm{G}_{1} 8_{9}\right)$ and as Listeria sp. $\left(\mathrm{G}_{9}\right)$. Subgroup B2, with an internal similarity of $90 \%$, contained strains received as Micro. thermosphactum. Subgroup B3, with an internal similarity of $95 \%$, contained three strains of Lact. mali. Subgroup B4, containing all strains received as Propionibacterium spp., was only just included in cluster B at $75 \%$ S (see Fig. I). Subgroup B5 was a rather loose cluster containing streptococci of different serological groups. Subgroup B6 (internal similarity $82 \%$ ) contained all the streptococci of serological groups D and Q with the exception of Strep.durans which fell in subgroup B5. Streptococcus uberis was loosely associated with subgroups B5 and B6.

Cluster C: 'Bacterium eurydice', Erysipelothrix, Gemella, Lactobacillus (in part), Streptococcus (in part). Subgroups $C_{1}$ (internal similarity $82 \%$ ) and $C_{2}$ (internal similarity $80 \%$ ) corresponded in the main to the subgenera Thermobacterium and Betabacterium (OrlaJensen, I919; Rogosa \& Sharpe, I959). Subgroup $\mathrm{C}_{3}$, a small homogeneous cluster (internal similarity $90 \%$ ), contained four strains received as $G$. haemolysans and $N$. haemolysans. Subgroup $\mathrm{C}_{4}$ contained three strains of 'Bact. eurydice' (internal similarity $90 \%$ ) and Brev. 
divaricatum which joined the 'Bact. eurydice' strains at $82 \%$ S. Subgroup C5 was a small group containing three strains of streptococci, one of serological group F and two morphological variants of serological group K. Subgroup C6 contained I I strains received as E. rhusiopathiae. Subgroup $\mathrm{C}_{7}$ contained five strains of Strep. suis. Subgroup C8 contained three strains of streptococci, one received as Strep. suis, one strain of serological group M and one strain of serological group $\mathrm{O}$.

Cluster D: Brevibacterium, Corynebacterium, Kurthia, Micrococcus. At $75 \% \mathrm{~S}$ this cluster comprised four subgroups. Subgroup DI contained all strains received as $K$. zopfi and joined subgroup D2, containing Brev. ammoniagenes, Brev. stationis and Micrococcus denitrifcans, at an S-level just below $80 \%$. Three strains received as Cell. rossica, Cor. mediolanum and Brev. leucinophagum joined subgroups DI and D2 at about $77 \%$ S. Subgroup D3 contained three strains, Cell. fimi, Cor.fascians and Cor. rathayi. A heterogeneous subgroup, D4 $(80 \% \mathrm{~S})$, contained three plant pathogenic corynebacteria, Brev. linens and Brev. imperiale.

Cluster E: Staphylococcus, Cor. insidiosum. This was a small cluster containing six strains (internal similarity $84 \%$ ).

Cluster F: Cellulomonas, Corynebacterium. At $78 \%$ this cluster comprised two subgroups: FI, containing Cellulomonas spp., Cor. diphtheriae and Cor. manihot, and F2 containing Brev. acetylicum and two strains received as 'Arthrobacter' spp. isolated from the human throat.

Table 2. Characteristics of some subgroups in computation C (Fig. 3) as percentages of positive reactions

No. of strains tested
Colonial characters:
Smooth
Edge entire
Elevation low convex
Elevation convex
Elevation 'fried egg'
Consistency watery
Consistency butyrous
Translucent
Emulsification homogeneous
Adheres to medium
Diameter $>3$ mm
$\beta$-Haemolysis
Slime production from sucrose
Stained preparations:
Beaded Gram stain
Long rods $>2 \mu \mathrm{m}$
Short rods $<2 \mu \mathrm{m}$
Filaments

No. of strains tested

Edge entire

Elevation low convex

Elevation convex

Consistency butyrous

Translucen

Emulsification homogeneous

$\beta$-Haemolysis

tained preparations:

Filaments

\begin{tabular}{|c|c|c|c|c|c|c|c|}
\hline 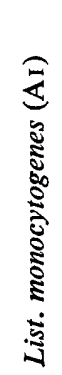 & 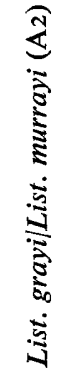 & 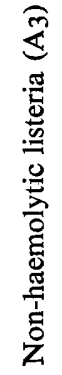 & 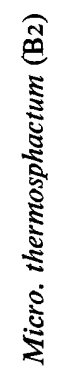 & 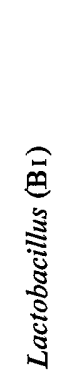 & 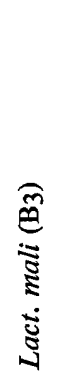 & 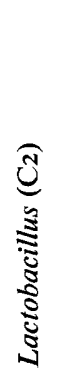 & 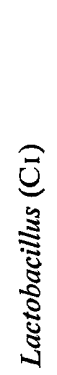 \\
\hline 37 & 7 & 3 & 25 & 6 & 3 & 7 & 9 \\
\hline 97 & 100 & 66 & 100 & 83 & 0 & 86 & 89 \\
\hline 22 & 14 & 0 & 4 & 17 & 0 & 29 & 0 \\
\hline 100 & 100 & 0 & 8 & 33 & 100 & 29 & 0 \\
\hline 0 & 0 & 0 & 0 & 0 & 0 & 0 & 0 \\
\hline 0 & 0 & 100 & 92 & 67 & 0 & $7 \mathrm{I}$ & 100 \\
\hline 97 & 100 & 100 & 50 & 83 & 66 & 71 & I I \\
\hline 3 & 0 & 0 & 50 & 17 & 33 & 29 & 89 \\
\hline 100 & 43 & 100 & 16 & 83 & 0 & 100 & 100 \\
\hline 100 & 100 & 100 & 40 & 100 & 66 & 86 & 89 \\
\hline 78 & 86 & 66 & 8 & 0 & 0 & 0 & I I \\
\hline 0 & 0 & 0 & 16 & 0 & 0 & 0 & 0 \\
\hline 92 & 0 & 0 & 0 & 0 & 0 & 0 & 0 \\
\hline 0 & 0 & 0 & 0 & 0 & 100 & 0 & 0 \\
\hline 0 & 0 & 0 & 100 & 100 & 100 & 100 & 100 \\
\hline 0 & 0 & 0 & 44 & 50 & 100 & 100 & 100 \\
\hline 100 & 100 & 100 & 56 & 50 & 0 & 0 & 0 \\
\hline 5 & 0 & 66 & 52 & 33 & 100 & 57 & 67 \\
\hline
\end{tabular}


Table 2 (cont.)

Stained preparations (cont.):

Cells in chains

Pleomorphism

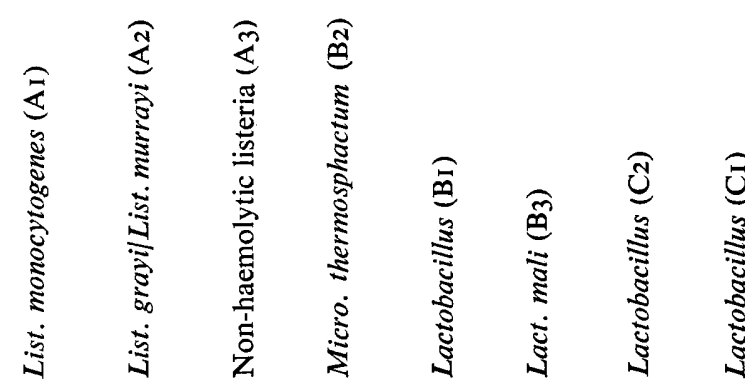

Pellet in liquid medium:

Stringy

Granular

Floccular

Easily suspended

Motility

Tumbling motility

Growth at:

$$
\begin{aligned}
& 5{ }^{\circ} \mathrm{C} \\
& 10{ }^{\circ} \mathrm{C} \\
& 35^{\circ} \mathrm{C} \\
& 45^{\circ} \mathrm{C} \\
& 50^{\circ} \mathrm{C}
\end{aligned}
$$

Anaerobic growth

Catalase

Acid from:

Inulin

Inositol

Dulcitol

Lactose

Methyl $\alpha$-glucoside

Melibiose

Salicin

Adonitol

L-Arabinose

Mannitol

Glycerol

Maltose

Rhamnose

D-Galactose

Sucrose

Sorbitol

Fructose

Xylose

Trehalose

Cellobiose

Melezitose

Raffinose

Gas from glucose

Gluconate oxidation

Degradation tests:

Aesculin

Arginine (aerobic)

Arginine (anaerobic)

Hippurate

Lecithinase

100

100
0

100

100

92

83

100

100

100

$100 \quad 100$

100

$$
\text { (0) }
$$

$$
\begin{array}{r}
100 \\
0 \\
0
\end{array}
$$$$
\begin{aligned}
& 0 \\
& 0
\end{aligned}
$$

96

$\begin{array}{llll}\circ & 0 & 43 & 33\end{array}$

100

97

97

0
100

100

100

100

$$
0
$$

o

$\begin{array}{rrrr}83 & 100 & 100 & 100 \\ 17 & 0 & 0 & 0 \\ 0 & 0 & 0 & 0 \\ 83 & 100 & 86 & 100 \\ 0 & 100 & 0 & 1 \text { I } \\ 0 & 0 & 0 & 0\end{array}$

$100 \quad 100$

100

100

IOO

IOO

100

100

50

$100 \quad 0 \quad$ I I

100

100
100

100

67
100

100

$\begin{array}{rr}43 & \text { I I } \\ 100 & 100\end{array}$

$\begin{array}{rr}3 & 0 \\ 97 & 100\end{array}$

97

100

100

0

$\begin{array}{lll}0 & 57 & 78\end{array}$

100

IOO

100

100

$100 \quad 100$

- $0 \quad 100$

96

$\begin{array}{llll}83 & 66 & 0 & 33\end{array}$

$$
\begin{array}{r}
0 \\
5 \\
95
\end{array}
$$

95
100

7 I

I00

100

100
96

67

$0 \quad 0 \quad 22$

I

100

100

100

83
100

$\begin{array}{lll}66 & 0 & 22\end{array}$

$86 \quad 33$

$100 \quad 100 \quad 100$

100

100

83

I0O $86 \quad 78$

$\begin{array}{lll}100 & 29 & 44\end{array}$

$\begin{array}{rll}66 & 7 \mathrm{I} & 44\end{array}$

$46 \quad 100 \quad 33$

96

100

$\begin{array}{rr}14 & 33 \\ 100 & 100\end{array}$

0
88

17

0

I0O

100

I00

100

100

83

83
100

0

100

100

$100 \quad 100$

I00

50

I9

$\begin{array}{rr}100 & 100 \\ 0 & 100\end{array}$

100
100

100

100

0
100

100

100

100

0
100

100

100

100

33

100

0

33
0

$43 \quad 0$

140

$\begin{array}{rr}0 & \text { I I } \\ 86 & 78\end{array}$

$0 \quad 0$

7 I 67

$86 \quad 56$

$\begin{array}{rr}0 & 0 \\ 86 & 67\end{array}$

$29 \quad 0$

I4 33

I4 33

I4 33

$100 \quad 100 \quad 100$

$86 \quad 44$

$86 \quad 0$

$\begin{array}{llllllll}0 & 0 & 0 & 0 & 17 & 0 & 14 & 0\end{array}$

$\begin{array}{rrrr}100 & 100 & 100 & 100 \\ 3 & 0 & 0 & \\ 0 & 0 & 33 & \\ 100 & 43 & 100 & \\ 84 & 86 & 33 & 5\end{array}$

83
0
0
50
100

$\begin{array}{rrr}100 & 14 & \text { I I } \\ 0 & 0 & 0 \\ 0 & 86 & 0 \\ 66 & 14 & 0 \\ 100 & 57 & 89\end{array}$ 
Table 2 (cont.)

\begin{tabular}{|c|c|c|c|c|c|c|c|c|}
\hline & 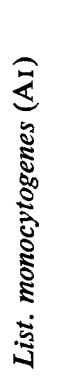 & 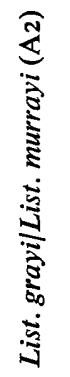 & 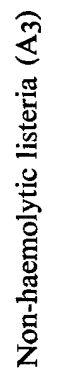 & 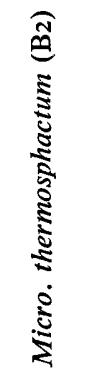 & 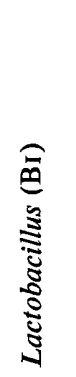 & 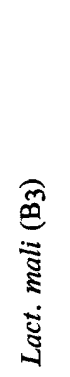 & 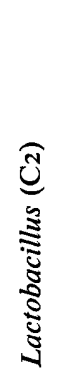 & 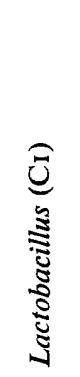 \\
\hline \multicolumn{9}{|l|}{ Degradation tests (cont.): } \\
\hline DNA & 100 & 100 & 100 & 100 & 50 & 33 & 57 & 100 \\
\hline RNA & 100 & 100 & 100 & 100 & 33 & 0 & 43 & 89 \\
\hline Starch & 8 & $7 \mathrm{I}$ & 0 & 24 & 100 & 0 & 100 & 100 \\
\hline Tween 40 & 0 & 0 & 0 & 8 & 17 & 0 & 14 & I I \\
\hline Tween 60 & 89 & o & 0 & 92 & 100 & 100 & 57 & 33 \\
\hline Tween 80 & 100 & 0 & 0 & 0 & 0 & 0 & 0 & II \\
\hline \multicolumn{9}{|l|}{ Carbon sources: } \\
\hline Pyruvate & 3 & 0 & 0 & 0 & o & $\circ$ & 29 & 0 \\
\hline Acetate & 3 & $\circ$ & 0 & 0 & 17 & 0 & 0 & 0 \\
\hline Propionate & 3 & 0 & 0 & 0 & 0 & 0 & 0 & II \\
\hline Citrate & 3 & o & 0 & 0 & 0 & 0 & 14 & I I \\
\hline Malate & 89 & 29 & 0 & 0 & 17 & $\circ$ & 0 & 0 \\
\hline Malonate & 0 & 14 & 0 & 0 & 33 & $\circ$ & I4 & II \\
\hline$\alpha$-Ketoglutarate & 3 & 0 & o & o & 0 & $\circ$ & 0 & 0 \\
\hline Salicylate & 3 & 0 & 0 & 0 & 33 & 0 & o & 0 \\
\hline \multirow{2}{*}{\multicolumn{9}{|c|}{$\begin{array}{l}\text { Growth in the presence of: } \\
\mathrm{NaCl}\end{array}$}} \\
\hline & & & & & & & $7 \mathrm{I}$ & II \\
\hline $10.0 \%(w / v)$ & 97 & 100 & 100 & 92 & 33 & 66 & 43 & II \\
\hline \multicolumn{9}{|l|}{ Potassium nitrite } \\
\hline $0.1 \%(w / v)$ & 95 & 86 & 100 & 0 & 0 & 0 & 0 & 0 \\
\hline \multicolumn{9}{|l|}{ Sodium azide } \\
\hline $0.01 \%(w / v)$ & 16 & 100 & 66 & 4 & 100 & 100 & 100 & 100 \\
\hline $0.02 \%(w / v)$ & 8 & 100 & 33 & 0 & 100 & 0 & 100 & 100 \\
\hline $0.05 \%(w / v)$ & 3 & 14 & 0 & 0 & 100 & 0 & 100 & 78 \\
\hline \multicolumn{9}{|l|}{ Potassium thiocyanate } \\
\hline $2.5 \%(w / v)$ & 100 & 100 & 100 & 84 & 100 & 100 & 100 & 44 \\
\hline $3.75 \%(w / v)$ & 100 & 100 & 100 & 0 & 100 & 100 & 100 & 22 \\
\hline $4.5 \%(w / v)$ & 100 & 100 & 100 & 0 & 50 & 100 & 86 & 22 \\
\hline \multicolumn{9}{|l|}{ Tetrazolium } \\
\hline $0.01 \%(\mathrm{w} / \mathrm{v})$ & 100 & 100 & 100 & 100 & 100 & 100 & 100 & 100 \\
\hline Reduction $0.01 \%(\mathrm{w} / \mathrm{v})$ & 100 & 100 & 100 & 100 & 83 & 0 & 100 & 78 \\
\hline $0.1 \%(w / v)$ & 97 & 100 & 100 & 48 & 67 & 100 & 86 & 56 \\
\hline Reduction $0.1 \%(\mathrm{w} / \mathrm{v})$ & 100 & 100 & 100 & 32 & 33 & 0 & 86 & 33 \\
\hline \multicolumn{9}{|l|}{ Reduction of potassium tellurite } \\
\hline $0.01 \%(w / v)$ & 100 & 100 & 100 & . 96 & 83 & 100 & 80 & 33 \\
\hline $0.025 \%(\mathrm{w} / \mathrm{v})$ & 100 & 100 & 100 & 68 & 33 & 66 & 80 & II \\
\hline $0.05 \%(\mathrm{w} / \mathrm{v})$ & 100 & 100 & 100 & 88 & 33 & 33 & 80 & 22 \\
\hline \multicolumn{9}{|l|}{ Sensitivity to: } \\
\hline Penicillin & 100 & 100 & 100 & 100 & 100 & 66 & 100 & 100 \\
\hline Streptomycin & 100 & 100 & 100 & 4 & 83 & 100 & 100 & 100 \\
\hline Sulphanilamide & 3 & 0 & 0 & 64 & 0 & 0 & 14 & 0 \\
\hline Novobiocin & 100 & 100 & 66 & 100 & 100 & 100 & 100 & 100 \\
\hline Nalidixic acid & 0 & $\circ$ & 0 & 100 & 0 & 0 & 0 & 0 \\
\hline Stimulation of growth by sulphanilamide & 68 & 43 & 0 & $\circ$ & 0 & 33 & 14 & II \\
\hline Voges Proskauer & 100 & 100 & 100 & 88 & 100 & 0 & o & II \\
\hline Reduction $\mathrm{NO}_{3} \rightarrow \mathrm{NO}_{2}$ & 0 & 43 & 0 & 0 & 0 & 0 & 0 & 0 \\
\hline Production of $\mathrm{H}_{2} \mathrm{~S}$ & 0 & 57 & 0 & 0 & 83 & 100 & 43 & 56 \\
\hline Urease & 0 & 0 & 33 & o & 0 & o & $\circ$ & o \\
\hline Phosphatase & 100 & 100 & 66 & 100 & 100 & 100 & 86 & 33 \\
\hline
\end{tabular}

All strains were Gram-positive; grew at 20 and $30{ }^{\circ} \mathrm{C}$; fermented glucose and utilized it as sole carbon source; grew in the presence of $0.01 \%, 0.02 \%, 0.03 \%(\mathrm{w} / \mathrm{v})$ thallous acetate; were indole and sulphatase negative; and were sensitive to chloramphenicol, chlortetracycline, erythromycin, oleandomycin, oxytetracycline and tetracycline. None survived heating at $60^{\circ} \mathrm{C}$ for $15 \mathrm{~min}$; nor produced $\mathrm{NH}_{3}$ from peptone; nor degraded casein, cellulose, Tween 20 , tyrosine or xanthine. 
Table 3. Characteristics of some subgroups in computation C (Fig. $3^{*}$ ) as percentages of positive reactions

No. of strains tested

Colonial characters:

Smooth

Edge entire

Edge rhizoidal

Elevation low convex

Elevation 'fried egg'

Consistency watery

Consistency butyrous

Translucent

Emulsification homogeneous

Adheres to medium

Diameter $>3 \mathrm{~mm}$

Pigment yellow

$\beta$-Haemolysis

$\alpha$-Haemolysis

Slime production from sucrose

Stained preparations:

Gram positive

Beaded Gram stain

Long rods $>2 \mu \mathrm{m}$

Short rods $<2 \mu \mathrm{m}$

Filaments

Cocci

Pleomorphism

Pellet in liquid medium:

Stringy

Granular

Floccular

Easily suspended

Motility

Growth at:

$$
\begin{aligned}
& 5{ }^{\circ} \mathrm{C} \\
& 10{ }^{\circ} \mathrm{C} \\
& 45^{\circ} \mathrm{C} \\
& 50^{\circ} \mathrm{C}
\end{aligned}
$$

Survival at $60^{\circ} \mathrm{C}$ for $15 \mathrm{~min}$

Anaerobic growth

Catalase

Acid from:

Inulin

Inositol

Dulcitol

Lactose

Methy] $\alpha$-glucoside

Melibiose

Salicin

Adonitol

L-Arabinose

Mannitol

Glycerol

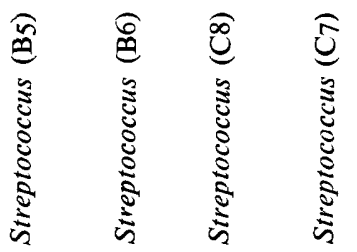

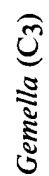

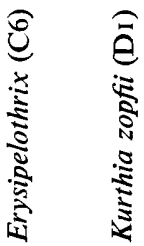

I I

8

4

5

4

I I

9

O $\quad 100$

100

100

100

100

$100 \quad 56$

0

0

100

0

100

0

100

0

75

75

0

0

50

25

25

I 00

9 I

IOO

0

0

0

0

100

89
0

o 100

1000

o 44

100

100
0

100
0

IOO

o

I00

100
25

$\begin{array}{ll}0 & 0 \\ 0 & 0\end{array}$

9I 100

o

9

64

o

I 8

18

I 8

9

9
100
9

100
9

$45 \quad 100$

18

27

82

55

36

73

36

18

18

18
100
0

100

100

0

50

100

0089

o I I

$\begin{array}{rr}0 & 0 \\ 27 & 56\end{array}$

$\begin{array}{rrrr}100 & 100 & 27 & 56 \\ 0 & 0 & 0 & 67\end{array}$

75
88

88

I3

60

100

25

100
63

63
75

IOO

100

100

100

100

50

75

63
0
25
25
0
0
100
25
50
0
0
100
0
0
25
0
0
25
0 $\begin{array}{rrrr}0 & 0 & 18 & 66 \\ 100 & 100 & 100 & 100 \\ 0 & 0 & 0 & 44 \\ 0 & 0 & 0 & 0 \\ 0 & 0 & 0 & 0 \\ 100 & 100 & 100 & 0 \\ 0 & 0 & 0 & 100\end{array}$

$\begin{array}{rrrr}80 & 0 & 0 & 0 \\ 0 & 0 & 0 & 0 \\ 0 & 0 & 0 & 0 \\ 100 & 0 & 100 & 0 \\ 100 & 0 & 0 & 0 \\ 100 & 0 & 0 & 0 \\ 100 & 0 & 0 & 0 \\ 0 & 0 & 0 & 0 \\ 0 & 0 & 0 & 0 \\ 0 & 0 & 0 & 0 \\ 0 & 0 & 0 & 67\end{array}$

27

MIC 98 
Table 3 (cont.)

Acid from (cont.):

Maltose

Rhamnose

D-Galactose

Sucrose

Sorbitol

Fructose

Xylose

Trehalose

Cellobiose

Melezitose

Raffinose

Glucose

Oxidative

Fermentative

Degradation tests:

Aesculin

Arginine (aerobic)

Arginine (anaerobic)

Hippurate

Lecithinase

DNA

RNA

Starch

Tween 20

Tween 40

Tween 60

Tween 80

Tyrosine

Carbon sources:

Glucose

Citrate

Malate

$\alpha$-Ketoglutarate

Salicylate

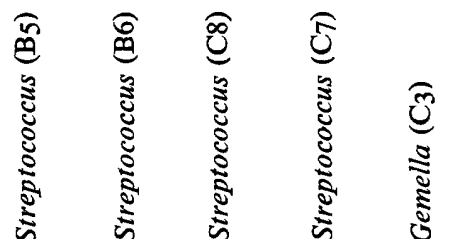

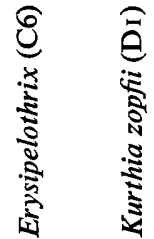

$100 \quad 100 \quad 100$

100

$\begin{array}{rrrr}9 & 50 & 25 & \\ 100 & 100 & 50 & 100 \\ 82 & 100 & 75 & 100\end{array}$

$100 \quad 100 \quad 0$

$82 \quad 100 \quad 75$

$\begin{array}{lll}9 & 63 & 25\end{array}$

100

$100 \quad 75$

$27 \quad 63$

6488

73

100

$\begin{array}{rr}9 & 88 \\ 55 & 100\end{array}$

50
50

50

0

100

100

IOO

80

100
100

100
80

100

$\begin{array}{rrr}0 & 0 \\ 100 & 100 & 100\end{array}$

0

0
100

$$
\text { o }
$$

100

62
18
73

$$
\begin{array}{r}
18 \\
13 \\
100
\end{array}
$$

100

45
0

100

75

100

0

0
100

20

100

0

0

100

0

20
0

20

91

9

IOO

100

Growth in the presence of:

$\mathrm{NaCl}$

$6.5 \%(w / v)$
$10.0 \%(w / v)$

Potassium nitrite $0.1 \%(w / v)$

Thallous acetate $0.02 \%(w / v)$ $0.03 \%(w / v)$

Sodium azide $0.01 \%(w / v)$ $0.02 \%(w / v)$ $0.05 \%(w / v)$

100

$100 \quad 100 \quad 44$

0 $0 \quad 25$

$\begin{array}{lll}64 & 88 & 75\end{array}$

00

0

0
100

o 1 I

$\begin{array}{rrr}100 & 9 & 22 \\ 0 & 0 & 0\end{array}$

50

0

18

I I

Potassium thiocyanate $2.5 \%(\mathrm{w} / \mathrm{v})$ $3.75 \%(w / v)$ $4.5 \%(w / v)$

$\begin{array}{rrrrrrr}91 & 100 & 50 & 100 & 100 & 82 & 100 \\ 55 & 100 & 50 & 80 & 100 & 64 & 100 \\ 9 & 0 & 50 & 100 & 0 & 0 & 89 \\ 100 & 100 & 100 & 100 & 100 & 100 & 89 \\ 100 & 100 & 100 & 100 & 100 & 100 & 89 \\ 100 & 100 & 75 & 20 & 100 & 91 & 0 \\ 100 & 100 & 25 & 0 & 100 & 91 & 0 \\ 45 & 100 & 0 & 0 & 100 & 0 & 0 \\ 36 & 88 & 0 & 0 & 100 & 0 & 100 \\ 9 & 88 & 0 & 0 & 100 & 0 & 100 \\ 0 & 50 & 0 & 0 & 100 & 0 & 67\end{array}$


Table 3 (cont.)

Growth in the presence of (cont.):

\begin{tabular}{|c|c|c|c|c|c|}
\hline 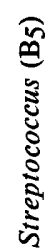 & 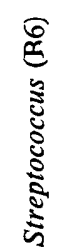 & 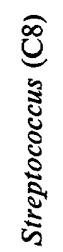 & 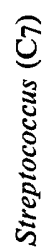 & 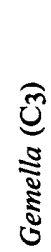 & 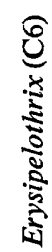 \\
\hline
\end{tabular}

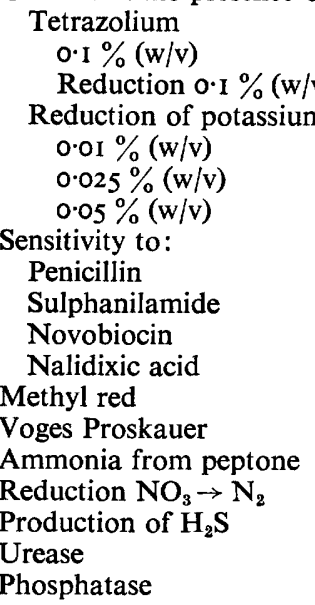

$\begin{array}{rrrrrrr}82 & 88 & 25 & 0 & 100 & 100 & 89 \\ 82 & 88 & 25 & 0 & 100 & 100 & 89 \\ 100 & 100 & 0 & 20 & 0 & 91 & 100 \\ 91 & 100 & 0 & 0 & 0 & 91 & 100 \\ 73 & 75 & 25 & 100 & 0 & 73 & 78 \\ 100 & 88 & 100 & 100 & 100 & 100 & 100 \\ 45 & 0 & 25 & 60 & 75 & 27 & 22 \\ 100 & 100 & 100 & 100 & 100 & 0 & 100 \\ 9 & 25 & 0 & 0 & 50 & 82 & 89 \\ 100 & 100 & 100 & 100 & 100 & 100 & 0 \\ 9 & 75 & 25 & 80 & 50 & 0 & 0 \\ 0 & 0 & 0 & 0 & 0 & 0 & 100 \\ 0 & 0 & 0 & 0 & 0 & 0 & 11 \\ 55 & 25 & 25 & 0 & 75 & 64 & 0 \\ 0 & 0 & 0 & 0 & 0 & 0 & 100 \\ 100 & 75 & 25 & 0 & 100 & 55 & 100\end{array}$

All strains formed chains; grew at 20,30 and $35^{\circ} \mathrm{C}$; grew in presence of $0.01 \%(w / v)$ thallous acetate and grew on and reduced $0.01 \%(w / v)$ tetrazolium; were indole, oxidase and sulphatase negative; and were sensitive to chloramphenicol, chlortetracycline, erythromycin, oleandomycin, oxytetracycline, streptomycin and tetracycline. No strains showed tumbling motility; produced gas from glucose; degraded casein, cellulose or xanthine; utilized acetate, malonate, propionate or pyruvate as carbon sources; reduced $\mathrm{NO}_{3}$ to $\mathrm{NO}_{2}$; nor oxidized gluconate.

* Kurthia zopfii strains are not included in Fig. 3 because they are too distantly related to the other taxa.

\section{Computation $B$}

This computation (Fig. 2) included the 13 strains omitted from computation A, and the two sets of results obtained with 46 representative strains tested at 30 and $35^{\circ} \mathrm{C}$. To accommodate these extra strains and results, 59 strains included in computation A were omitted.

There was reasonably good accord between the relationships of the strains in the two computations. The composition of cluster A was the same in both. So, in the main, was cluster B, but subgroup B4 (Propionibacterium) moved to join cluster E (Fig. 1) containing staphylococci and Cor. insidiosum at $77 \%$ S. In cluster C, subgroup $\mathrm{C}_{5}$ [streptococci of serological groups $\mathrm{F}$ and $\mathrm{K}$ (Fig. I)] merged with the large heterogeneous streptococcal subgroup B5. Also, whereas in cluster C (Fig. I), Lact. acidophilus (G6I) showed a relationship to other lactobacilli in subgroup $\mathrm{C}_{2}$, in computation B (Fig. 2) it moved to show a low level of relationship to some streptococci in subgroup C8. The relationship between strains in clusters $\mathrm{D}$ and $\mathrm{F}$ was not markedly affected despite the fact that far fewer strains from these clusters were included in computation $\mathrm{B}$. 


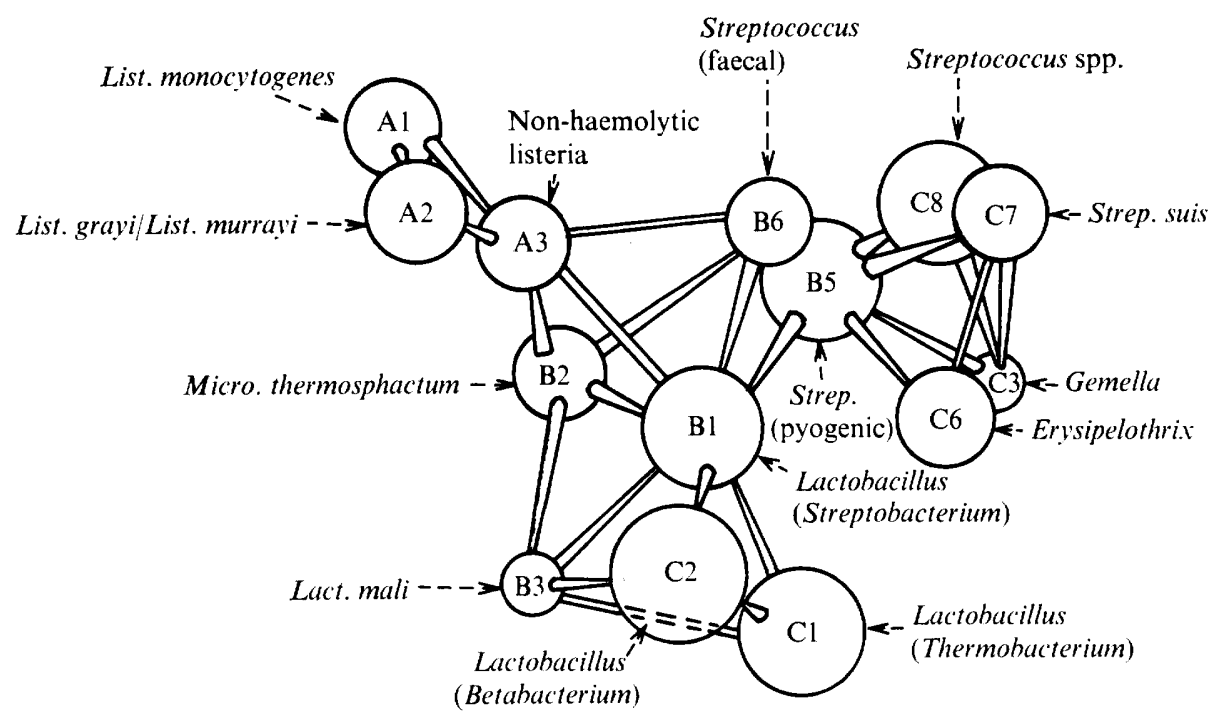

Fig. 3. Model depicting approximate spatial relationships between the taxa (except Kurthia) included in computation $\mathbf{C}$.

\section{Computation $C$}

This computation was performed on 140 strains from area I (Figs I and 2) representing the taxa Erysipelothrix, Gemella, Lactobacillus, Listeria, Microbacterium thermosphactum, Streptococcus, and nine strains of $K$. zopfii. The data were further analysed by the IGROUPS and PRINTRES programs to determine the tests of importance in the characterization of groups in this area. A model (Fig. 3) showing the approximate spatial relationships of the inter- and intra-group similarities in area I was constructed from this data. Tables 2 and 3 list the test results characteristic of the groupings shown in Fig. 3, plus $K$. zopfii (Table 3).

\section{Reproducibility}

Reproducibility of microbiological tests is receiving increasing attention (Sneath \& Collins, 1974). The effect of such errors on bacterial classification has been discussed by Sneath \& Johnson (1972).

In the present study all the tests were repeated on approximately $25 \%$ of the strains and 46 strains were subjected to the same battery of tests incubated at 30 and $35{ }^{\circ} \mathrm{C}$. In addition five strains were divided into two and treated as separate cultures in all tests.

The five pairs of duplicate cultures showed a similarity between $88.5 \%$ and $92.7 \%$ to their respective partners giving an average discrepancy of $9 \%$. A comparison of the two sets of data obtained on the same strains cultured at 30 and $35{ }^{\circ} \mathrm{C}$ showed a discrepancy of I I $\%$. The data obtained from the tests performed on the same strains at the same temperature, but at different times, showed an average error of about $15 \%$.

This last figure is high compared with earlier studies (Lapage et al., 1970; Sneath \& Johnson, 1972; Jones, 1975a). An analysis of the results showed that the error was due to the results of morphological tests, where interpretation is largely subjective, and to the results of tests such as growth at various temperatures, where slight changes in conditions of incubation can have a marked effect on the results. However, the duplicate tests were only performed on $25 \%$ of the strains (see above) and we are of the opinion that the effect of this test error on the clustering of the bacteria was less than the information lost by the omission of these results for all the strains (for discussion, see Sneath, 1972). 


\section{DISCUSSION}

The grouping of the strains into two main areas, one containing Erysipelothrix, Gemella, Lactobacillus, Listeria, Micro. thermosphactum, Propionibacterium and Streptococcus, the other Brevibacterium, Corynebacterium, Kurthia, Micrococcus (Figs I and 2), agrees with the results of previous studies which suggested that the genus Listeria is more closely related to the lactic acid bacteria than to the coryneform bacteria (Davis et al., 1969; Stuart \& Pease, I972; Jones, I975a).

Area II contained those bacteria which were included mainly as marker organisms and thus, with the exception of the genus Kurthia, were represented only by single strains. The clustering of all the $K$. zopfii strains as a homogeneous group $(85 \% \mathrm{~S})$, but with indications of two separate clusters within the taxon, is in keeping with earlier findings (Keddie, 1949; Gardner, I969; Jones, I975a) and the grouping of the marker strains is in good accord with the results of Bousfield (1972) and Jones (1975a).

The grouping in area I of the strains of the genus Propionibacterium, the type strain of List. denitrificans and three strains of 'Bact. eurydice' was unexpected. The numerical taxonomic results of Seyfried (1968) indicated that the genera Loctobacillus and Propionibacterium were 'distinct in their relationship' and in a similar, but broader, study (Jones, 1975a), the genus Propionibacterium grouped as a distinct taxon more closely related to the corynebacteria than to the lactic acid bacteria. The \% guanine + cytosine (GC) base ratio ( 57 to $68 \%$, Johnson \& Cummins, 1972) is in keeping with the results of Jones (I975a). However, although the propionibacteria grouped in area I in the present study, the position of the taxon was not stable. In computation A it showed a relationship to Lact. mali (Fig. I), while in computation B it formed a loose association with strains of Staph. aureus and Cor. insidiosum (Fig. 2). Little is yet known about the effect of the composition of the groups of bacteria studied on clustering at levels higher than that of genus. At these taxonomically higher levels, the 'distances' between genera may be roughly equal. Hence, just which way an intermediate genus (in this case Propionibacterium) will cluster at a higher level may depend on sampling error.

The clustering of the one strain of List. denitrificans ( $\%$ GC 55; Stuart \& Welshimer, 1973) in area I so close to other representatives of the genus Listeria (\% GC 35; Stuart \& Welshimer, 1973) is also not easy to explain. Neither is the discrepancy between the association of the three strains of 'Bact. eurydice' with the genera Gemella and Lactobacillus in the present study and its apparent relationship to some corynebacteria in the study of Jones (1975a). However, Jones (I975a) noted that when the test results of two groups of strains ( $75 \%$ of which were common to both groups) were computed, the main taxa remained constant in their relationship to each other, but poorly represented taxa or single strains, which were not the type strains of good taxa, moved. It must be accepted that single strains may not always represent taxa very well, but the remedy here is to conduct further studies on more strains of these poorly sampled species. The differences in the relationship of certain taxa to each other noted between studies carried out in different laboratories may be due as much to the number and type of bacteria studied as to the selection of tests and test reproducibility.

\section{Intrageneric relationships of Listeria}

All the strains received as Listeria species, with the exception of $\mathrm{G}_{9}$, group together at $83 \% \mathrm{~S}$ (cluster $\mathrm{A}$ ). Within this cluster the appearance of three subgroups corresponding to List. monocytogenes (AI), List. grayi/List. murrayi (A2), Listeria spp. (A3) and one strain of List. denitrificans $\left(\mathrm{G}_{43}\right)$ is only in partial agreement with the results of previous workers 
Table 4. Characters which differentiate between the three main taxa in the genus Listeria and List. denitrificans

\begin{tabular}{|c|c|c|c|c|c|}
\hline & $\begin{array}{l}\text { List. } \\
\text { monocytogenes }\end{array}$ & $\begin{array}{l}\text { List. } \\
\text { grayi and }\end{array}$ & $\begin{array}{c}\text { List. } \\
\text { murrayi }\end{array}$ & $\begin{array}{l}\text { Non-haemolytic } \\
\text { listeria (A3) }\end{array}$ & $\begin{array}{l}\text { List. } \\
\text { denitrificans }\end{array}$ \\
\hline$\beta$-Haemolysis & $+(92 \%)$ & - & - & - & - \\
\hline Motility & $+(97 \%)$ & + & + & - & + \\
\hline Catalase & $+(97 \%)$ & + & + & - & + \\
\hline Voges Proskauer & + & + & + & + & - \\
\hline Nitrate reduction & - & - & + & - & + \\
\hline Arginine hydrolysis & - & - & - & $+(33 \%)$ & - \\
\hline Cellulose hydrolysis & - & - & - & - & + \\
\hline Ribonuclease & + & + & + & + & - \\
\hline $\mathrm{H}_{2} \mathrm{~S}$ production & - & $+(25 \%)$ & + & - & - \\
\hline Acid production from: & & & & & \\
\hline L-Arabinose & - & $+(25 \%)$ & - & $+(33 \%)$ & + \\
\hline D-Galactose & $+(19 \%)$ & + & + & + & + \\
\hline Inositol & - & - & - & + & - \\
\hline Inulin & - & - & - & + & - \\
\hline Lactose & $+(95 \%)$ & + & + & + & + \\
\hline Mannitol & $+(8 \%)$ & + & + & + & - \\
\hline Raffinose & $+(8 \%)$ & + & + & $+(66 \%)$ & + \\
\hline Rhamnose & $+(95 \%)$ & - & $+(66 \%)$ & $+(33 \%)$ & - \\
\hline Sucrose & $+(5 \%)$ & - & - & + & + \\
\hline
\end{tabular}

+ , Positive (figures in parentheses indicate \% positive, otherwise all strains positive); -, negative.

(Stuart \& Pease, I972; Stuart \& Welshimer, 1973, 1974; Jones, 1975a). The surprising association of List. denitrificans at $86 \% \mathrm{~S}$ with subgroup A2 (List. grayi/List. murrayi) has been discussed above.

All previous studies have indicated the separate identity of List. monocytogenes and this has also been shown by our results. As was noted by Stuart \& Pease (1972) and Wilkinson \& Jones (1975), no correlation could be detected between serovars and physiological groupings within this species.

Strains of List. grayi and List. murrayi clustered together at $90 \% \mathrm{~S}$ and although two distinct subgroupings can be seen they do not correlate with the names carried by the strains. Therefore the suggestion of Stuart \& Welshimer (1973, 1974) that there are two distinct species, List. grayi and List. murrayi, is premature. Listeria murrayi, in our opinion, should be regarded as a biovar of List. grayi.

The recovery of subgroup $\mathrm{A}_{3}$ is interesting. Two of the three strains were isolated as nonhaemolytic variants or contaminants from haemolytic cultures of List. monocytogenes (GI5A and GI6A) and the other (G8) was isolated as List. monocytogenes from the brain of a cow by the late E. G. D. Murray. Further work is required to clarify the taxonomic relationships of these non-haemolytic strains. Non-haemolytic strains of List. monocytogenes have been isolated with increasing frequency in the past two years $(\mathrm{H}$. Seeliger, personal communication). The characteristics of the Listeria subgroups are listed in Table 4.

\section{Intergeneric relationships of Listeria}

The relationship of Listeria to the genera Erysipelothrix, Gemella, Lactobacillus and Streptococcus and to the taxon Micro. thermosphactum supports the results of previous numerical taxonomic studies (Davis et al., 1969; Stuart \& Pease, 1972; Jones, 1975a). However, the relationship is not close enough (Figs I, 2 and 3 ) to justify including any of the Listeria subgroupings in any one of the above genera. 
Microbacterium thermosphactum appears as a distinct group. This is in accord with the results of biochemical and DNA base ratio studies (Collins-Thompson et al., 1972), and numerical taxonomic studies (Davis et al., 1969, Stuart \& Pease, 1972; Jones, 1975a), and with the recent proposal that strains of Micro. thermosphactum be placed in the new genus Brochothrix (Sneath \& Jones, 1976).

The Lactobacillus strains clustered as four distinct subgroups, one of which (B3) contained all the representatives of the homofermentative species Lact. mali isolated from cider (Carr \& Davies, 1970). The other three subgroups corresponded closely to the subgenera proposed by Orla-Jensen (1919) and extended by Rogosa \& Sharpe (1959).

The recovery of most of the Streptococcus strains in four main subgroups is in good agreement with the physiological divisions established by Sherman (1937) and extended by Sharpe, Fryer \& Smith (1966).

With the exception of Strep. durans (Gi24) all the faecal streptococci formed one subgroup (B6) with an internal structure corresponding to the 'enterococcus' and 'viridans' subdivisions of the faecal streptococci (Deibel, 1964; Jones, Sackin \& Sneath, 1972). This subgroup showed the closest relationship of any of the Streptococcus subgroups to the genus Listeria, a result in agreement with those of Davis et al. (1969) and Stuart \& Pease (1972). Of interest is the loose association of Strep. uberis ('viridans' division of Sherman, 1937) with subgroups B5 and B6. All but one of the Strep. suis strains (Strep. suis Gr4I) clustered as subgroup $\mathrm{C}_{7}$ and showed the closest association to a small subgroup containing Strep. suis (GI4I) and one strain each of serological groups M and O. The taxonomic position of Strep. suis is not clear. Elliott (1966) demonstrated that strains of Strep. suis contained the antigen of serological group D and suggested (Elliott, 1966) that Strep. suis was probably related to Strep. bovis. However, work in our laboratory has shown no close relationship between Strep. suis and Strep. bovis nor between Strep. suis and any of the other streptococci of serological group D (D. Jones, unpublished), and our present results agree with this opinion.

Buchanan \& Gibbons (1974) include Gemella haemolysans and strains previously named Neisseria haemolysans in the genus Gemella in the family Streptococcaceae. Our results agree with this classification.

Erysipelothrix rhusiopathiae emerges as a distinct taxon showing no close relationship to the genus Listeria; indeed, it exhibits a much closer relationship to the subgroups formed by the genus Gemella and the streptococci. These findings are in agreement with the results of Davis et al. (1969) and Stuart \& Pease (1972).

In the latest edition of Bergey's Manual of Determinative Bacteriology (Buchanan \& Gibbons, 1974) the genera Erysipelothrix and Listeria are treated as genera of uncertain taxonomic affiliation in Part 16 which also includes the family Lactobacillaceae. However, the family Streptococcaceae is listed in quite a different section and Micro. thermosphactum is included in the genus Microbacterium which is listed as a genus incertae sedis in the coryneform group.

Stuart \& Welshimer (1974) have suggested the creation of a new family Listeriaceae to accommodate the monospecific genus Listeria (comprising List. monocytogenes) and the genus Murraya to contain the species Murraya grayi and Murraya grayi subsp. murrayi. If one accepts this, the result is three family groupings, Lactobacillaceae, Listeriaceae and Streptococcaceae, plus at least two other taxa, Erysipelothrix and Micro. thermosphactum, amongst the bacteria which cluser in area I of this study. A case can be made for the inclusion of Erysipelothrix in the family Streptococcaceae, although there would undoubtedly be opposition on the grounds of cell shape. However, the higher taxonomic relationship of 
Micro. thermosphactum is more perplexing for it falls halfway between the listeriae and lactobacilli (see Fig. 3). It could be argued that Micro. thermosphactum is at present a solitary taxon which represents a number of as yet poorly studied bacteria. If this is the case, our results, and those of previous workers, indicate that we can expect even more blurring of the boundaries between the family Lactobacillaceae and the proposed family Listeriaceae (Stuart \& Welshimer, 1974).

A good case can be made for including the taxa Erysipelothrix, Gemella, Lactobacillus, Listeria, Streptococcus and Micro. thermosphactum in one family: the Lactobacillaceae. Objections to this suggestion will probably be, firstly, that the suggested family grouping would embrace some taxa which have a rod-like cellular morphology and others which have a coccoid cell shape, and secondly, the grouping would contain some taxa which possess a fully functional cytochrome system and catalase and others which do not. Both cell shape and the presence of catalase have been regarded as important identification characters amongst groups of bacteria which have a very similar physiology. But how important taxonomically are these two characters? Many workers have commented on the effect of medium and age on the shape of bacteria; indeed, List. monocytogenes can be almost coccoid and is frequently mistaken for faecal streptococci on first isolation, while filaments are very common in old laboratory strains (Seeliger, 196I). Similarly, streptococci of serological group D may appear quite rod-like (Jones, 1959). Recent studies by London \& Kline (1973) on the protein homologies of the malic enzymes and aldolases of rods and cocci in the lactic area indicated a close affinity between Lact. casei and Strep. faecalis and these authors concluded that shape is a relatively trivial character which should not be used to divide groups which are closely related on other criteria. In our opinion this applies more so when the shapes of individual bacteria are subject to quite marked variation.

For many years, the absence of catalase (and by implication, cytochromes) was considered a characteristic of the Streptococcaceae and the Lactobacillaceae. However, as pointed out by Smith (1954), the electron transport systems and associated enzymes of bacteria vary from species to species and with growth conditions. This has been shown to be true even of the lactic acid bacteria. Haem and non-haem catalases have been detected amongst this group (Felton, Evans \& Niven, 1953; Wheater, 1955; Whittenbury, 1960, 1964; Delwiche, I96I; Delwiche \& Johnson, 1962) and, more recently, functional cytochromes have been detected in streptococci under certain growth conditions (Bryan-Jones \& Whittenbury, 1969; Ritchie \& Seeley, 1974). The catalase reaction of Micro. thermosphactum can be equivocal, although it contains a fully functional cytochrome system (Davidson \& Hartree, 1968). The catalase reaction of List. monocytogenes depends on the composition of the basal medium (Jones, $1975 a$ ) and there is disagreement about whether this species contains cytochromes. Trivett \& Meyer (197I) could not detect cytochromes in List. monocytogenes but Jones (unpublished results), using more sensitive methods, found low levels to be present.

These observations raise interesting evolutionary and taxonomic questions, as has already been pointed out by Bryan-Jones \& Whittenbury (1969) with regard to the presence of cytochromes in streptococci, and in our opinion support the case for inclusion of all the taxa in Fig. 3 in one family, the Lactobacillaceae. Additionally this family might include the pediococci and leuconostocs not included in the present study. A study of the relationship of the hetero-fermentative cocci to the hetero-fermentative lactobacilli would be very interesting and it is a pity time did not allow their inclusion in this work. 


\section{CONCLUSIONS}

I. The genus Listeria is a distinct taxon containing at least two species, List. monocytogenes and List. grayi. The relationships of certain non-haemolytic listeriae to the genus Listeria requires further study.

2. Erysipelothrix is quite distinct from Listeria and shows a close relationship to the streptococci.

3. Strains named Microbacterium thermosphactum form a distinct group worthy of genus rank. They are not related to the genus Kurthia.

4. The genus Lactobacillus contains four groupings corresponding to Betabacterium, Streptobacterium, Thermobacterium and Lact. mali.

5. The genus Streptococcus contains at least four distinct groups and all show a relatively close relationship to the genera Gemella and Erysipelothrix.

6. Listeria clusters with other lactic acid bacteria and in our opinion should be included in the family Lactobacillaceae together with the genera Erysipelothrix, Gemella, Lactobacillus, and Streptococcus and with the distinct taxon formed by strains of Micro. thermosphactum.

We thank Professor P. H. A. Sneath for advice and one of us (B. J. W.) thanks the Medical Research Council for the award of a Research Training Scholarship.

\section{REFERENCES}

Bousfield, I. J. (1972). A taxonomic study of some coryneform bacteria. Journal of General Microbiology 77, $44 \mathrm{I}-455$.

BreEd, R. S., Murray, E. G. D. \& SMTth, N. R. (1957). Bergey's Manual of Determinative Bacteriology, 7th edn. London: Baillière, Tindall \& Cox.

BRYAN-JoNes, D. G. \& WHITtenBury, R. (1969). Haematin-dependent oxidative phosphorylation in Streptococcus faecalis. Journal of General Microbiology 58, 247-260.

Buchanan, R. E. \& GibBons, N. E. (1974). Bergey's Manual of Determinative Bacteriology, 8th edn. Baltimore: Williams \& Wilkins.

CARR, J. G. \& DAvIES, P. A. (1970). Homofermentative lactobacilli of ciders including Lactobacillus mali nov. spec. Journal of Applied Bacteriology 33, 768-774.

Collins, C. H. \& LYNE, P. M. (1970). Microbiological Methods, 3rd edn, p. 109. London: Butterworths.

Collins-Thompson, D. L., Sørhaug, T., Wirter, L. D. \& ORdal, Z. J. (1972). Taxonomic consideration of Microbacterium lacticum, Microbacterium flavum and Microbacterium thermosphactum. International Journal of Systematic Bacteriology 22, 65-72.

CowAN, S. T., \& Steel, K. J. (1965). Manual for the Identification of Medical Bacteria. Cambridge: Cambridge University Press.

DA Silva, G. A. N., \& HoLT, J. G. (1965) Numerical taxonomy of certain coryneform bacteria. Journal of Bacteriology 90, $92 \mathrm{I}-927$.

Davidson, C. M. \& HARTREE, E. F. (1968). Cytochrome as a guide to classifying bacteria: taxonomy of Microbacterium thermosphactum. Nature, London 220, 502-504.

DAvIS, G. H. G. (I955). The classification of lactobacilli from the human mouth. Journal of General Microbiology $13,48 \mathrm{I}-493$.

Davis, G. H. G., Fomin, L., Wilson, E. \& Newton, K. G. (1969). Numerical taxonomy of Listeria, streptococci and possibly related bacteria. Journal of General Microbiology 57, 333-348.

Davis, G. H. G. \& Newton, K. G. (I969). Numerical taxonomy of some named coryneform bacteria. Journal of General Microbiology 56, 195-214.

DeIBEL, R. H. (1964). The group D streptococci. Bacteriological Reviews 28, 330-366.

DelWICHE, E. A. (I96I). Catalase of Pediococcus cerevisiae. Journal of Bacteriology 8r, 416-4I8.

Delwiche, E. A. \& JoHnson, M. A. (1962). The distribution and properties of the catalases of the Lactobacillaceae. Abstracts, VIIIth International Congress of Microbiology, p. 33. Montreal: I.A.M.S.

De MAN, J. C., Rogosa, M. \& Sharpe, M. E. (1960). A medium for the cultivation of lactobacilli. Journal of Applied Bacteriology 23, $130-136$.

ELLIOTT, S. D. (1966). Streptococcal infection in young pigs. I. An immunochemical study of the causative agent (PM Streptococcus). Journal of Hygiene 64, 205-212. 
Errebo Larsen, H. \& Seeliger, H. P. R. (I966). A mannitol fermenting Listeria strain: L. grayi. In 3rd International Symposium on Listeriosis, pp. 35-39. Edited by J. Donker-Voet, R. G. Dijkstra, E. H. Kampelmacher, B. E. Kingma and R. P. Mouton. Utrecht: Rijks Institut.

Felton, E. A., Evans, J. B. \& Niven, C. F. (I953). Production of catalase by pediococci. Journal of Bacteriology $65,48 \mathrm{I}-482$.

GARDNER, G. A. (1969). Physiological and morphological characteristics of Kurthia zopfii isolated from meat products. Journal of Applied Bacteriology 32, 37 I-380.

Hugh, R. \& LeIfSON, E. (I953). The taxonomic significance of fermentative versus oxidative metabolism of carbohydrates by various Gram-negative bacteria. Journal of Bacteriology 66, 24-26.

Johnson, J. L. \& Cummins, C. S. (I972). Cell wall composition and deoxyribonucleic acid similarities among the anaerobic coryneforms, classical propionibacteria and strains of Arachnia propionica. Journal of Bacteriology 109, 1047-1066.

Johnson, R. \& SNEATH, P. H. A. (1973). Taxonomy of Bordetella and related organisms of the families Achromobacteriaceae, Brucellaceae and Neisseriaceae. International Journal of Systematic Bacteriology 23, 38I-404.

Jones, D. (1959). Physiological and serological studies on group D streptococci. M.Sc. thesis, University of Reading.

JONES, D. (1975a). A numerical taxonomic study of coryneform and related bacteria. Journal of General Microbiology 87, 52-96.

JONES, D. (1975 b). The taxonomic position of Listeria. In Problems of Listeriosis, pp. 4-I7 Edited by M. Woodbine. Leicester: Leicester University Press.

Jones, D., Sackin, M. J. \& Sneath, P. H. A. (I972). A numerical taxonomic study of streptococci of serological group D. Journal of General Microbiology 72, I-I 2.

Keddie, R. M. (1949). A study of Bacterium zopfii Kurth. Dissertation, Edinburgh School of Agriculture.

KLINGE, K. (1960). Differential techniques and methods of isolation of Pseudomonas. Journal of Applied Bacteriology 23, 442-462.

Lapage, S. P., Bascomb, S., Willcox, W. R. \& Curtis, M. A. (i970). Computer identification of bacteria. In The Society for Applied Bacteriology, Technical Series 4: Automation, Mechanisation and Data Handling, pp. I-22. Edited by A. Bailey and R. J. Gilbert. London: Academic Press.

London, J. \& KLINE, K. (1973). Aldolase of lactic acid bacteria: a case history in the use of an enzyme as an evolutionary marker. Bacteriological Reviews 37, 453-478.

Murray, E. G. D., Webb, R. A. \& SwanN, M. B. R. (I926). A disease of rabbits characterised by large mononuclear leucocytosis caused by a hitherto undescribed bacillus Bacterium monocytogenes (n. sp.) Journal of Pathology and Bacteriology 29, 407-439.

Orla-Jensen, S. (1919). The Lactic Acid Bacteria. Copenhagen: Andr. Fred. Host \& Son.

Ritchie, T. W. \& SeEley, H. W. (1974). Cytochromes in Streptococcus faecalis var. zymogenes grown in a haematin-containing medium. Journal of General Microbiology 85, 220-228.

Rogosa, M. \& Sharpe, M. E. (I959). An approach to the classification of the lactobacilli. Journal of Applied Bacteriology 22, 329-340.

Seeliger H. P. R. (I96I). Listeriosis, 2nd edn. New York: S. Karger.

SeYfried, P. L. (I968). An approach to the classification of lactobacilli using computer-aided numerical analysis. Canadian Journal of Microbiology $14,313-318$.

Sharpe, M. E., Fryer, T. F. \& Smith, D. G. (I966). Identification of the lactic acid bacteria. In The Society for Applied Bacteriology, Technical Series I: Identification Methods for Microbiologists, pp. 63-79. Edited by M. B. Gibbs and F. A. Skinner. London: Academic Press.

Sherman, J. M. (I 937). The streptococci. Bacteriological Reviews I, 3-97.

SMITH, L. (1954). Bacterial cytochromes. Bacteriological Reviews 18, 106-1 30.

SNeAth, P. H. A. (1957). The application of computers to taxonomy. Journal of General Microbiology $\mathbf{1 7}$, $201-226$.

SNEATH, P. H. A. (1960). A study of the bacterial genus Chromobacterium. Iowa State Journal of Science 34, 243-500.

SNEATH, P. H. A. (1972). Computer taxonomy. Methods in Microbiology 7A, 29-98.

SNeAth, P. H. A. \& Collins, V. G. (I974). A study in test reproducibility between laboratories: report of a Pseudomonas Working Party. Antonie van Leeuwenhoek 40, 48I-527.

SNEATH, P. H. A. \& CowAN, S. T. (1958). A electro-taxonomic survey of bacteria. Journal of General Microbiology r9, 55I-565.

SNeAth, P. H. A. \& Johnson, R. (1972). The influence on numerical taxonomic similarities of errors in microbiological tests. Journal of General Microbiology 72, 377-392.

SNEATH, P. H. A. \& JoNes, D. (1976). Brochothrix, a new genus tentatively placed in the family Lactobacillaceae. International Journal of Systematic Bacteriology 26, 102-104.

SNeAth, P. H. A. \& Skerman, V. B. D. (1966). A list of type and reference strains of bacteria. International Journal of Systematic Bacteriology 16, I-133. 
SOKAL, R. R. \& MICHENER, C. D. (1958). A statistical method for evaluating systematic relationships. Kansas University Science Bulletin 38, I409-1438.

SteVENS, M. (1969). Development and use of multi-inoculation test methods for a taxonomic study. Journal of Medical Laboratory Technology 26, 253-263.

StuART, M. R. \& PeASE, P. E. (1972). A numerical study of the relationships of Listeria and Erysipelothrix. Journal of General Microbiology 73, 55 I-565.

StUART, S. E. \& Welshimer, H. J. (I973). Intrageneric relatedness of Listeria Pirie. International Journal of Systematic Bacteriology 23, 8-I4.

StUART, S. E. \& Welshimer, H. J. (1974). Taxonomic re-examination of Listeria Pirie and transfer of Listeria grayi and Listeria murrayi to a new genus Murraya. International Journal of Systematic Bacteriology 24, 177-185.

ThorNLEY, M. J. (1960). The differentiation of $\boldsymbol{P}_{\text {seudomonas }}$ from other gram-negative bacteria on the basis of arginine metabolism. Journal of Applied Bacteriology 23, 37-52.

TrivetT, T. L. \& MeYer, E. A. (197I). Citrate cycle and related metabolism of Listeria monocytogenes. Journal of Bacteriology 107, $770-779$.

WELSHIMER, H. J. \& MEREDITH, A. L. (I971). Listeria murrayi sp. n.: a nitrate-reducing mannitol-fermenting Listeria. International Journal of Systematic Bacteriology 21, 3-7.

WHEATER, D. M. (1955). The characteristics of Lactobacillus plantarum, L. helveticus and L. casei. Journal of General Microbiology 12, 133-139.

WhITTENBURY, R. (1960). Two types of catalase activity in lactic acid bacteria. Nature, London 187, 433-434.

WhitTENBURY, R. (1964). Hydrogen peroxide formation and catalase activity in the lactic acid bacteria. Journal of General Microbiology 35, 13-26.

WILKINSON, B. J. (1973). A numerical taxonomic and serological study of Listeria and possibly related bacteria. Ph.D. thesis, University of Leicester.

WILKINSON, B. J. \& JoNES, D. (I975). Some serological studies on Listeria and possibly related bacteria. In Problems of Listeriosis, pp. 25I-26I. Edited by M. Woodbine. Leicester: Leicester University Press.

Wirson, G. S. \& Miles, A. A. (1964). Topley \& Wilson's Principles of Bacteriology and Immunity, vol. I, 5th edn. London: Arnold. 